\title{
純シリカを添加したイットリア安定型立方晶ジルコニア (8Y-CSZ)の破壊鞔性*1
}

\author{
平賀啓二郎*2 森田孝治金 炳男 目 義雄
}

物質 · 材料研究機構材料研究所

J. Japan Inst. Metals, Vol. 69, No. 10 (2005), pp. 928-932

(C) 2005 The Japan Institute of Metals

\section{Fracture Toughness of Yttria-Stabilized Cubic Zirconia (8Y-CSZ) Doped with Pure Silica}

Keijiro Hiraga*2, Koji Morita, Byung-Nam Kim and Yoshio Sakka

National Institute for Materials Science, Ibaraki 305-0047

In yttria-stabilized cubic zirconia, the addition of $0.15-5$ mass \% pure silica introduces a glass phase dispersing uniformly along grain-boundary facets and at multiple junctions. For a grain size of 0.75 or $1.7 \mu \mathrm{m}$, the dispersion of the glass phase decreases the elastic modulus, the Vickers hardness and the elastic modulus-to-hardness ratio, whereas it affects little in the fracture toughness measured by an indentation method. The latter result arises because the decrease in the elastic modulus-to-hardness ratio is compensated by a decrease in the crack length for a given indentation load. Inspection of crack-propagation paths indicates that the glass phase with sizes smaller than those of the matrix grains is not a site for easy crack-propagation, but provides a site for a crack-deflection mechanism.

(Received July 11, 2005; Accepted August 29, 2005)

Keywords: cubic zirconia, silica addition, glass phase, fracture toughness, crack propagation path, crack deflection

\section{1. 緒言}

固体電解質や酸素センサーなどの高温電気化学デバィ $ス^{1,2}$ に広く用いられるイットリア $\left(\mathrm{Y}_{2} \mathrm{O}_{3}\right)$ 安定型立方晶ジル コニア $(\mathrm{Y}-\mathrm{CSZ})$ では, 少量の純シリカ $\left(\mathrm{SiO}_{2}\right)$ の添加が次の 利点をもたらすとされる.すなわち， 5 mass\%以下であれ ば, $\mathrm{SiO}_{2}$ 添加は電気伝導率に大きな低下を生じることなく3) 焼結時の粒成長を強く抑制し4), 超塑性の発現を可能にす る5)。これより，Y-CSZの超塑性を利用した電解質やセン サーのニアネット成形への応用が開けるものと期待されてい る3,5). ただし，上記のデバイスが外部応力や熱応力を受け ること, また, 変態強化 6,7$) の$ 働かない $\mathrm{Y}-\mathrm{CSZ}$ では破壊靶性 值が 1.3-2.2 $\mathrm{MPa} \cdot \mathrm{m}^{1 / 2}$ 程度 ${ }^{8-11)}$ と低いことから, $\mathrm{SiO}_{2}$ 添加 が破壊強度に及ぼす影響を知ることが不可欠である。しか し, 純 $\mathrm{SiO}_{2}$ や $\mathrm{SiO}_{2}$ 基ガラスの添加が機械的性質に及ぼす影 響については, $\mathrm{Y}_{2} \mathrm{O}_{3}$ 安定型正方晶ジルコニア $(\mathrm{Y}-\mathrm{TZP})$ の超 塑性 ${ }^{12-16)}$, 低温脆化 ${ }^{17-19)}$ および変態強化 ${ }^{17,20)}$ に関する報告 に限られており, 上記の超塑性発現に関する報告を除くと, 立方晶ジルコニアを対象とした検討を見受けない.

したがって本研究では, 結晶粒をほぼ一定に保って純 $\mathrm{SiO}_{2}$ を添加した $\mathrm{Y}-\mathrm{CSZ}$ を対象に, $\mathrm{SiO}_{2}$ 添加に伴う組織と 破壊靱性の変化挙動について明らかにすることを目的とした.

\footnotetext{
*1 Mater. Trans. 45(2004) 3324-2077 に掲載

*2 Corresponding author, E-mail: HIRAGA.keijiro@nims.go.jp
}

\section{2. 実 験 方 法}

20 mass ppm の $\mathrm{SiO}_{2}$ を不純物として含む純度 $99.9 \%$ 以 上, 平均粒子径 $25 \mathrm{~nm}$ の $8 \mathrm{~mol} \% \mathrm{Y}_{2} \mathrm{O}_{3}$ 安定型立方晶ジルコ ニア微粉末 $(8 \mathrm{Y}-\mathrm{CSZ}$, 東ソ一)を出発材とした.これに, コ ロイダルシリカ(SNOWTEX-O, 日産化学)を用いて, 0.15, 0.7, 2.0 および 5.0 mass \%の $\mathrm{SiO}_{2}$ を添加した. 所定量の 8Y-CSZ 微粉体, コロイダルシリカ, エタノール抢よび高純 度の Y-TZP ボール(ニッカトー)をポリエチレン容器に封入 して $24 \mathrm{~h}$ ボールミル混合の後に乾燥させ， 250 メッシュの 篩で分級して成型用粉体とした. この粉体の公称不純物濃度 は mass ppm 単位で $\mathrm{Na}_{2} \mathrm{O}$ が $700, \mathrm{Al}_{2} \mathrm{O}_{3}$ が 50 未満, $\mathrm{Fe}_{2} \mathrm{O}_{3}$ が 50 である.これを $20 \mathrm{MPa}$ の片押しプレスで成形の後, $400 \mathrm{MPa}$ の等方静水圧プレスを施した. 成形体の緻密化は 大気中 $1200-1400^{\circ} \mathrm{C}$ で 2-38 h の一段ないし二段焼結21)で行 った．温度と時間の組み合わせは， 1 および $2 \mu \mathrm{m}$ 近傍の二 通りの粒径に対して相対密度が $99.8 \%$ 以上となるように調 整した.ここで, 粒径 $d$ は研磨断面上における結晶粒の等 面積円の平均直径を 1.56 倍した值 22 で定義した. 無添加の 8Y-CSZ は粒成長が著しく, 相対密度が 95\%に達した段階 で粒径が $5 \mu \mathrm{m}$ を越えたために, 検討対象から除外した.

焼結組織の観察と計測には査型電子顕微鏡 (SEM, JSM6500F)ならびに画像処理ソフト (Optimas 6.5, Media Cybernetics）を用い, 熱腐食後に白金蒸着を施した研磨面上で行

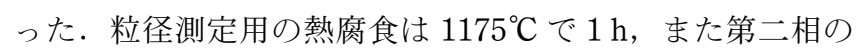
生成挙動の検討には, 粒界グルービングを抑制するために 
$1125^{\circ} \mathrm{C}$ で $1 \mathrm{~h}$ 行った。採取画像のコントラストを最適化処 理 ${ }^{23)}$ した後, 熱腐食面上における等面積円の直径が $25 \mathrm{~nm}$ 以上の結晶粒ならびに第二相について寸法と面積率を計測し た。

破壊靫性試験は以下のインデンテーション法24)によっ た. 厚さ $4 \mathrm{~mm}$ で幅が約 4-5 $\mathrm{mm}$ の試料を焼結材から切り 出して試験面を鏡面研磨の後, ひずみ除去の目的で, 大気中 $1175^{\circ} \mathrm{C}$ で $1 \mathrm{~h}$ 焼鈍の後に炬冷した. ビッカース圧子の挿入 は荷重 $P=98 \mathrm{~N}$ で $15 \mathrm{~s}$ 行った. この条件の下, すべて供試 材で, 圧痕亀裂の長さ $2 C$ とビッカース圧痕の対角線長さと の比は 4.0 を越えた. さらに $P=9.8-98 \mathrm{~N}$ で $P$ と $2 C^{3 / 2}$ との 間に比例関係が，また試験後に䢃開させた破面にメディアン 亀裂の形成がそれぞれ確認された。これより, 破壊靶性值を 式 ( 1$)^{24)}$ によって算出した.

$$
K_{\mathrm{IC}}=0.016\left(E / H_{\mathrm{v}}\right)^{1 / 2}\left(P / C^{3 / 2}\right),
$$

ここで $H_{\mathrm{v}}$ はビッカース硬さ，Eは弾性率である． $E$ の值 は，供試材にヌープ圧子を荷重 $49 \mathrm{~N}$ で圧入して得た圧痕の 弾性戻り量25)を画像解析 ${ }^{20,23)}$ によって分解能 $0.6 \mu \mathrm{m}$ で計測 して求めた.

\section{3. 実験結果および考察}

\section{1 焼結組織}

0.7, 2.0 抢よび 5.0 mass\%の $\mathrm{SiO}_{2}$ を添加した試料で，目 標とした $99.8 \%$ 以上の相対密度と平均粒径 $0.75 \pm 0.03 \mathrm{~mm}$ ならびに $1.67 \pm 0.03 \mathrm{~mm}$ との組み合わせが得られた。 0.15 mass\%添加材では, 相対密度 $99.8 \%$ における最小の平均粒 径は $2.4 \mu \mathrm{m}$ であった. $\mathrm{SiO}_{2}$ 添加量の多寡によらず， $\mathrm{Cu}-\mathrm{K} \alpha$ 線による X 線回折では, 結晶相として立方晶のジルコニア 相 $\left(\mathrm{ZrO}_{2}\right)$ のみが検出された.
Fig. 1 に示すように, $\mathrm{SiO}_{2}$ を添加した $8 \mathrm{Y}-\mathrm{CSZ}$ には，母 地よりも暗いコントラストをもって均一に分散する相が観察 される. エネルギー分散型 X 線分光 (EDS)ならびに X 線回 折の結果から,この相は $\mathrm{Si}$ の濃縮したガラス相と同定され た. ガラス相の集積(ポケット)は主に粒界の多重点に生じて おり, $\mathrm{SiO}_{2}$ 添加量が $2 \%$ 以上の試料では粒界ファセットに 沿っても認められた (Fig. 1(c) および (d)). $\mathrm{SiO}_{2}$ 添加量の増 加とともにガラスポケットの数と寸法は増加するが, 添加量 が $5 \%$ に達してもポケットの寸法は $\mathrm{ZrO}_{2}$ の粒径よりも小さ い値に留まっていた。

Fig. 2 に, $\mathrm{SiO}_{2}$ 添加量とガラス相の体積率 $V_{\mathrm{g}}$ との関係を 示す. 計測に際して等面積円の直径が $25 \mathrm{~nm}$ よりも小さな ガラスポケットを無視したが，これによる䛊差 $\delta V_{\mathrm{g}}$ は以下 のように見積もられる．結晶粒のすべての綾線 (三重線)に沿 って断面積 $A_{\mathrm{g}}=(25 / 2)^{2} \pi \mathrm{nm}^{2}$ のガラス相が存在すると仮定 し, 式( 2$)^{26)}$ を用いると $\delta V_{\mathrm{g}}$ の上限值が得られる.

$$
\delta V_{\mathrm{g}}=8 A_{\mathrm{g}} / \pi d^{2} \text {. }
$$

本研究の $d=0.75 \mu \mathrm{m}$ と $1.7 \mu \mathrm{m}$ に対してそれぞれ $\delta V_{\mathrm{g}}=0.2$ と $0.04 \mathrm{vol} \%$ であり，顕著な量とはならない.

Fig. 2 に示すように， $V_{\mathrm{g}}$ は $\mathrm{SiO}_{2}$ 添加とともに $0.30 \mathrm{vol} \%$ (0.15 mass $\% \mathrm{SiO}_{2}$ ) から 12.5 vol\% $\%$ mass $\left.\% \mathrm{SiO}_{2}\right)$ までほぼ 直線的に増加する. また, 同一の添加量に対して粒径が増す と $V_{\mathrm{g}}$ がわずかに増加する. $\mathrm{ZrO}_{2}$ 粒への $\mathrm{Si}$ の固溶量は無視 できる程度27)であることから, 以上の結果は, Si の粒界偏 析3,14,16) に飽和点があり, それを越えた分がガラス相を形成 するとして説明できる. $\mathrm{SiO}_{2}$ 添加 $3 \mathrm{Y}-\mathrm{TZP}$ の検討15) から得 られる $\mathrm{Si}$ 偏析の飽和值 $\left(25 \mathrm{pmol} \cdot \mathrm{mm}^{-2}\right)$ と結晶粒の平均切 片長さ $L$ から求をる単位体積中の粒界面積 $2 / L$ を用いると, $d=0.75 \mu \mathrm{m}$ に対して Fig. 2 に破線で示す見積もりが得ら れ，実測量が再現される.
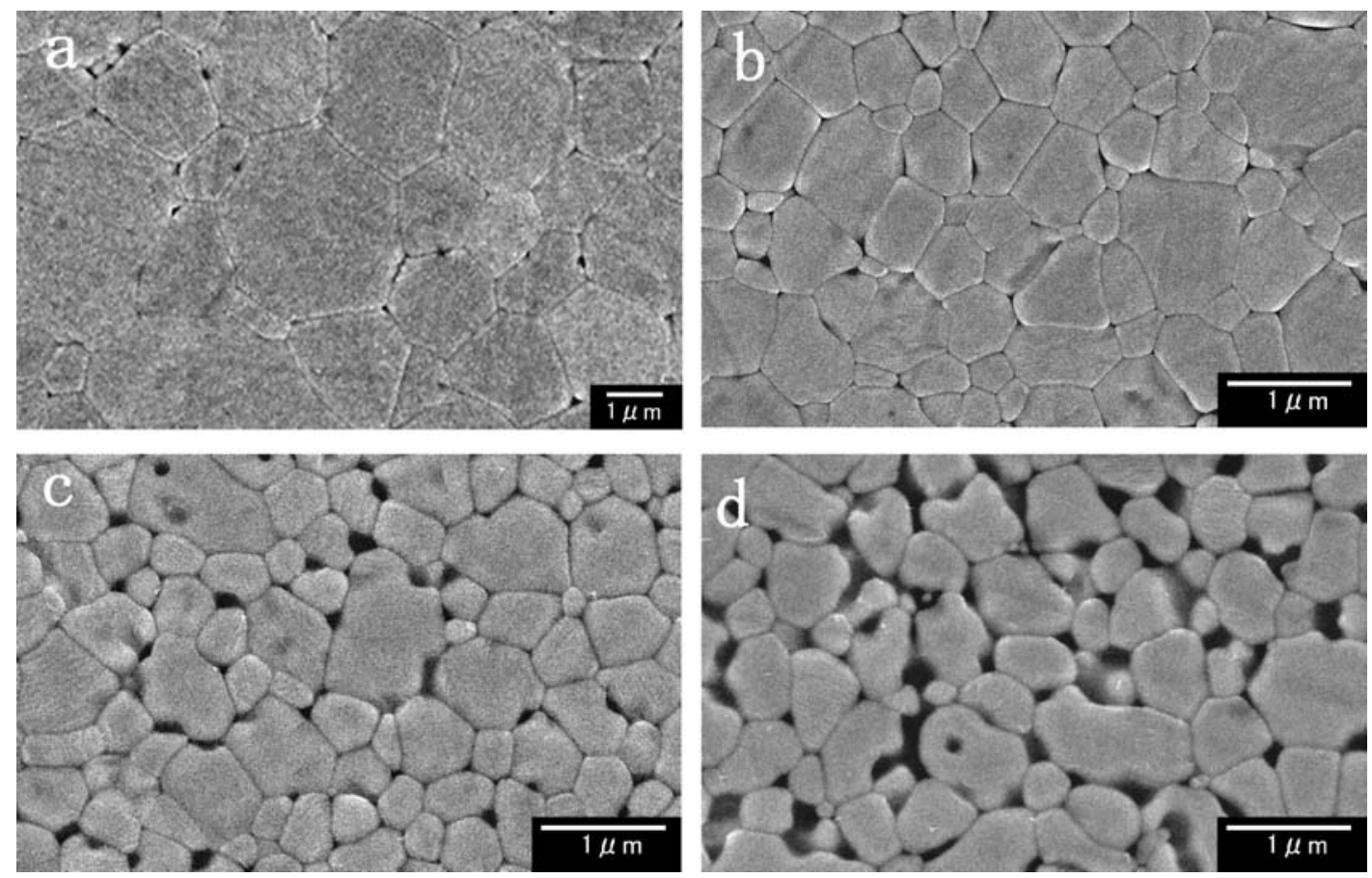

Fig. 1 Microstructural evolution accompanying pure $\mathrm{SiO}_{2}$ addition: scanning electron micrographs of materials with (a) 0.15 , (b) 0.7 , (c) 2.0 and (d) 5.0 mass $\% \mathrm{SiO}_{2}$. The average grain size was $2.4 \mu \mathrm{m}$ for (a) and $0.75 \mu \mathrm{m}$ for (b) trough (d). 


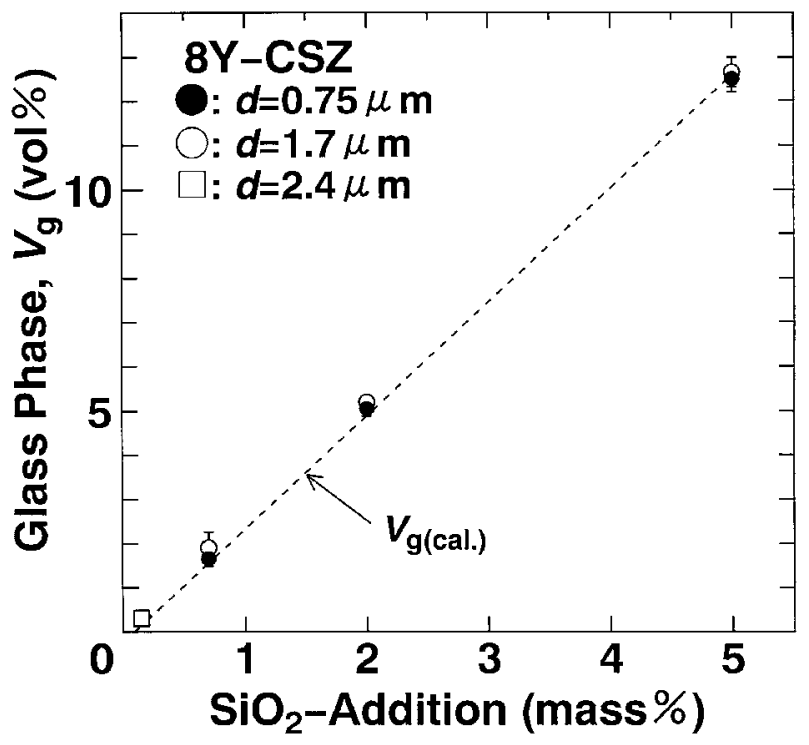

Fig. 2 Volume fraction of the glass phase as a function of pure $\mathrm{SiO}_{2}$ addition. The dashed line $\left(V_{\mathrm{g} \text { (cal. })}\right)$ is a calculation assuming the saturation of $\mathrm{Si}$ ions along grain boundaries.

\section{2 破壊靫性}

Fig. 3 に弾性率, ビッカース硬さ抢よび破壊靶性值とガラ ス相の量との関係を示す。粒径の増大によって同一の $\mathrm{SiO}_{2}$ 添加に対するデータ点がわずかに大 $V_{\mathrm{g}}$ 側に移動することを 除いて，これらの特性值は今回調べた範囲の粒径変化に対し て依存性を示さない。一方，ガラス相の量への依存性は弾性 率抢よび硬さの場合と破壊勒性值の場合とで異なっている.

Fig. 3(a)に見られるように, 弾性率と硬さは分散するガ ラス相の量とともに減少する.この傾向は, 非晶質の純 $\mathrm{SiO}_{2}{ }^{10)}$ や $\mathrm{SiO}_{2}$ 基ガラス24,25)の $E$ および $H_{\mathrm{v}}$ の值が無添加 8Y-CSZ の值のそれぞれ約 $30 \%$ および $50 \%$ おるることか ら, 混合測の観点から見て妥当である.ただし， $V_{\mathrm{g}}$ の増加 に伴う弾性率の減少は，混合した特性の上限を与える通常の 並列 (Voigt) モデル28)よりも急峻である. 同様のことは $\mathrm{SiO}_{2}$ 基ガラス添加型 $3 \mathrm{Y}-\mathrm{TZP}$ のデータ12)にも現れている. 急峻 な減少については, $\mathrm{Si}$ の粒界偏析の昂進や $\mathrm{ZrO}_{2} / \mathrm{SiO}_{2}$ 界面 の増加に関連する可能性もあり, 検討の余地があると思われ る. この可能性とは別に, 混合した特性の下限を与える直列 (Reuss) モデル28)によっても実験結果を説明できる.すなわ ち，一定の負荷荷重に対して，ガラス相が担う応力と $\mathrm{ZrO}_{2}$ 相の担う応力とが同じであれば， $V_{\mathrm{g}}$ の増加に伴って $E$ は急 速に減少する. 前者の応力が後者のそれの $\alpha$ 倍 $(>1.0)$, す なわちガラス相に応力が集中する場合は, $E$ の減少はさらに 大きくなる．以上のことは次式で表される．

$$
E_{\mathrm{m} \cdot \mathrm{g}}=E_{\mathrm{m}} E_{\mathrm{g}} /\left\{\left(1-V_{\mathrm{g}}\right) E_{\mathrm{g}}+\alpha V_{\mathrm{g}} E_{\mathrm{m}}\right\},
$$

ここで $\mathrm{m} \cdot \mathrm{g}, \mathrm{m}$ および $\mathrm{g}$ はそれぞれ $\mathrm{ZrO}_{2}$ とガラス相の混合 体, $\mathrm{ZrO}_{2}$ 母相抢よびガラス相を示す. $E_{\mathrm{g}}$ に $\mathrm{SiO}_{2}$ 基ガラス の下限值 $(60 \mathrm{GPa})$ と $\alpha=1.0$ あるいは $E_{\mathrm{g}}$ に非晶質 $\mathrm{SiO}_{2}$ の值 $\left(73 \mathrm{GPa}^{29)}\right)$ と $\alpha=1.4$ を仮定すると, Fig. 3(a)の破線で示す ように実測值が再現される.

一方，8Y-CSZ の破壊勒性はガラス相が分散しても減少せ ず， $V_{\mathrm{g}}$ が約 $12 \mathrm{vol} \%$ まで増加するとその值はわずかに増加

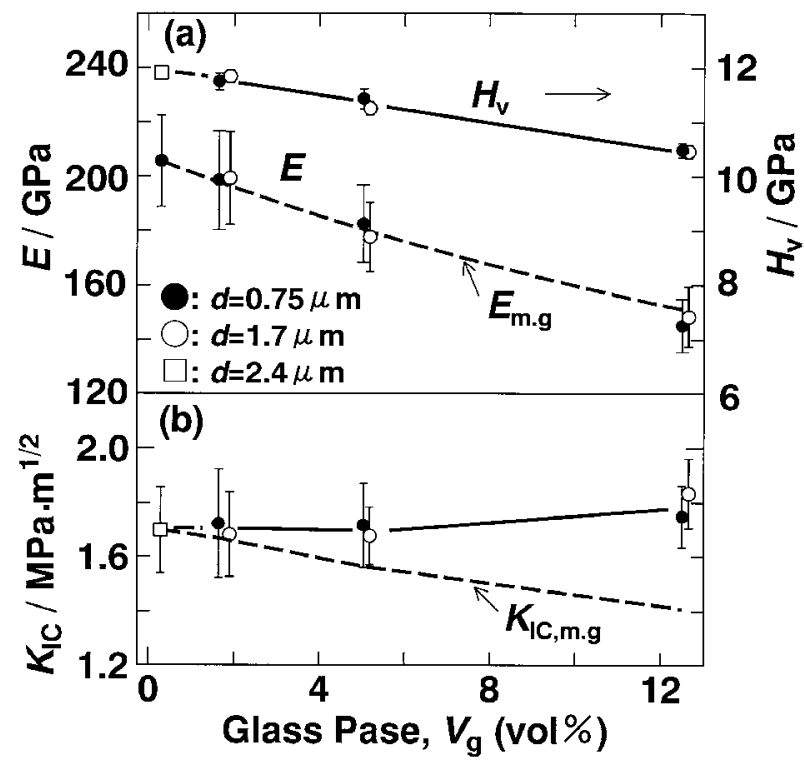

Fig. 3 (a) The elastic modulus, $E$, and the Vickers hardness, $H_{\mathrm{v}}$ and (b) fracture toughness, $K_{\mathrm{IC}}$, as a function of the amount of the glass phase. The dashed lines drawn in (a) and (b) are the calculations of eqs. (3) and (5), respectively.

する.この結果は一般的に考えられる予想とは以下の点で異 なっている、第一に，Y-TZP に関する既存研究12,18)では, ガラス相は亀裂の容易伝播経路とされている.したがって, その分散は破壊勒性值 ${ }^{22,18)}$ の低下や亀裂伝播速度の増大 ${ }^{18)}$ 招くと予想される．第二に，非晶質 $\mathrm{SiO}_{2}$ や $\mathrm{SiO}_{2}$ 基ガラスの 実験值 $\left(K_{\mathrm{IC}}=0.6-0.8 \mathrm{MPa} \cdot \mathrm{m}^{1 / 2}\right.$ および $E=60-80$ $\left.\mathrm{GPa}^{24,25,30,31)}\right)$ は, $8 \mathrm{Y}-\mathrm{CSZ}$ に対する值 $\left(K_{\mathrm{IC}}=1.3-2.2 \mathrm{MPa}\right.$. $\mathrm{m}^{1 / 2}$ 抢よび $\left.E=210-220 \mathrm{GPa}^{8-11)}\right)$ の半分ないしそれ以下で あることも， $V_{\mathrm{g}}$ の増大とともに破壊勒性值が低下すること を予期させる.

上記のマイナス効果については破壊靯性 $J_{\mathrm{IC}}$ (エネルギー開 放率)の混合則32)を仮定して見積もることができる.

$$
J_{\mathrm{IC}, \mathrm{m} \cdot \mathrm{g}}=\left(1-V_{\mathrm{g}}\right) J_{\mathrm{IC}, \mathrm{m}}+V_{\mathrm{g}} J_{\mathrm{IC}, \mathrm{g}} \text {. }
$$

この式は $J_{\mathrm{IC}, \mathrm{m} \cdot \mathrm{g}}$ の上限, すなわちガラス相の混入によるマ イナス効果の下限見積もりに相当する. ただし, 複合組織化 したことに起因するマイナスあるいはプラスの付加的効果を 含んでいない. $J_{\mathrm{IC}}=K_{\mathrm{IC}}^{2}(1-v) / E$ の関係を用い, $\mathrm{SiO}_{2}$ 相分 散によるポアソン比 $v$ の変化を無視すると, 式 $(4)$ は以下の ように書き換えられる.

$K_{\mathrm{IC}, \mathrm{m} \cdot \mathrm{g}} \approx\left\{E_{\mathrm{m} \cdot \mathrm{g}}\left[\left(1-V_{\mathrm{g}}\right) K_{\mathrm{IC}, \mathrm{m}}^{2} / E_{\mathrm{m}}+V_{\mathrm{g}} K_{\mathrm{IC}, \mathrm{g}}^{2} / E_{\mathrm{g}}\right]\right\}^{1 / 2} . \quad$ ( 5$)$ 0.15 mass \% 添加材の $K_{\mathrm{IC}}$ と $E$ をそれぞれ母相の值とみな し, 非晶質シリカの值 $\left.K_{\mathrm{IC}, \mathrm{g}}=0.79 \mathrm{MPa} \cdot \mathrm{m}^{1 / 2} 31\right)$ および $E_{\mathrm{g}}=$ $73 \mathrm{GPa}$ を用いると Fig. 3(b)の破線で示す予測が得られる.

このように, マイナス効果に対する下限側見積もりであって も, $V_{\mathrm{g}}$ の増加に伴って, 破壊靭性值が実験誤差の範囲を越 えて減少することが予測される.

以上のような予測と異なって破壊勒性值がガラス相の分散 に対して鈍感な理由を圧痕データから検討した. Fig. 4 に示 すように, ガラス相の分散は弾性率と硬さの比 $E / H_{\mathrm{v}}$ および 一定の負荷荷重に対する亀裂長さ $C$ をともに減少させてい る.この結果, 式 $(1)$ に抢ける $\left(E / H_{\mathrm{v}}\right)^{1 / 2}$ の減少が $P / C^{3 / 2}$ 


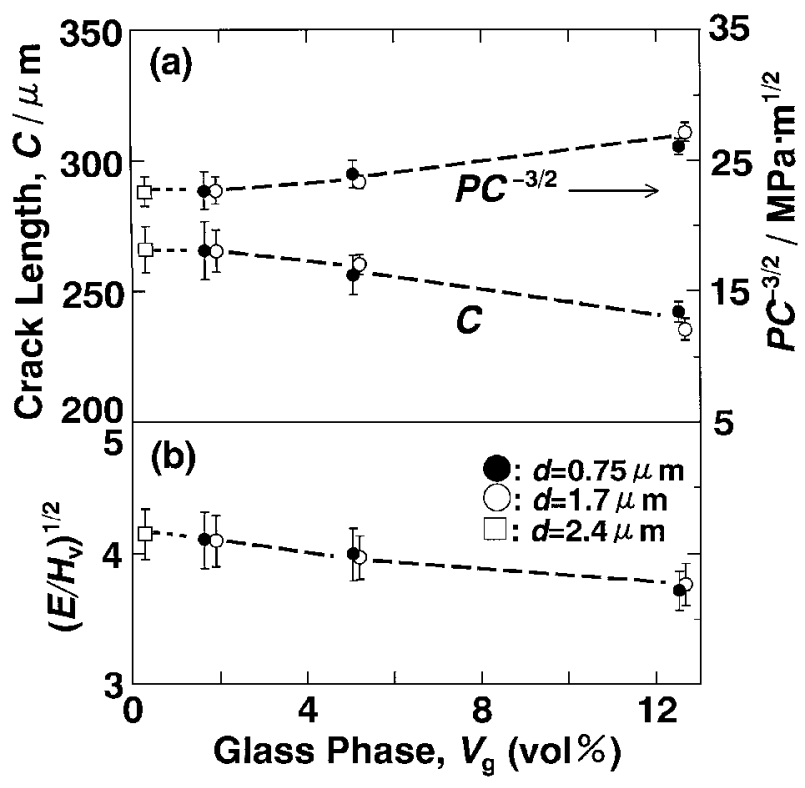

Fig. 4 The indentation-crack length and the modulus-tohardness ratio as a function of the amount of the glass phase.

の増大によって相殺され， $K_{\mathrm{IC}}$ の值がガラス相の分散に対し て鈍感になることが分かる.Fig. 3(b) 抢よ゙゙ Fig. 4(a)の データは，ガラス相の分散が，亀裂伝播に抵抗として働く何 らかの機構を惹起することを示唆している。

\section{3 亀裂の伝播挙動}

Fig. 5 に示すように，亀裂は $\mathrm{ZrO}_{2}$ 母相の粒内 $(\mathrm{z}), \mathrm{ZrO}_{2}$ 母相の粒界 $(\mathrm{z} / \mathrm{z}), \mathrm{ZrO}_{2}$ とガラス相の間の界面 $(\mathrm{z} / \mathrm{g})$ 抢よび ガラス相内部 $(\mathrm{g})$ の 4 経路を伝播することが観察された. 亀 裂の分岐や主亀裂近傍域での微視亀裂の形成は認められなか った. Fig. 5 はまた，それぞれの伝播経路の割合が $\mathrm{SiO}_{2}$ の 添加量とともに変化することを示している. ガラス相がわず かしか形成されない 0.15 mass\%添加(Fig. 5(a))では粒内伝 播が主体を占め, 添加量が増すとほかの経路の頻度が増加し ている (Fig. 5(b)-(d)). 無添加材を含む Y-CSZ 基材料に関 する既存研究8-11,33) は粒内が優先的な伝播経路であると一貫 して報告しているので, Fig. 5(b)-(d) に見られる挙動は Y$\mathrm{CSZ}$ では新しい様相である.さらに, 亀裂の微視的形状も $\mathrm{SiO}_{2}$ 添加とともに変化している。すなおち, 亀裂は 0.15 mass\%添加では直線的でその縁も滑らかであるが，添加量 が増すと粒界や $\mathrm{ZrO}_{2}$ /ガラス相界面に沿ったジグザク状にな っている.

以上の様相を定量的に調べるために，伝播経路 i が全経路 で占める割合 $F_{\mathrm{i}}$ を以下のように定義した。

$$
F_{\mathrm{i}}=L_{\mathrm{i}} / L_{\mathrm{t}},
$$

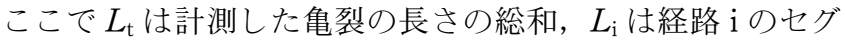
メントの総和である. また, 亀裂の微視的なジグザク度 $R$ を以下によって調べた。

$$
R=L_{\mathrm{t}} / L_{\mathrm{p}},
$$

ここで $L_{\mathrm{p}}$ は巨視的な亀裂進展方向に投影した亀裂の長さの 総和である。この定義によって，Rの值は理想的に滑らかで 直線的な亀裂に対して 1.0 であり, ジグザグの程度が増すほ
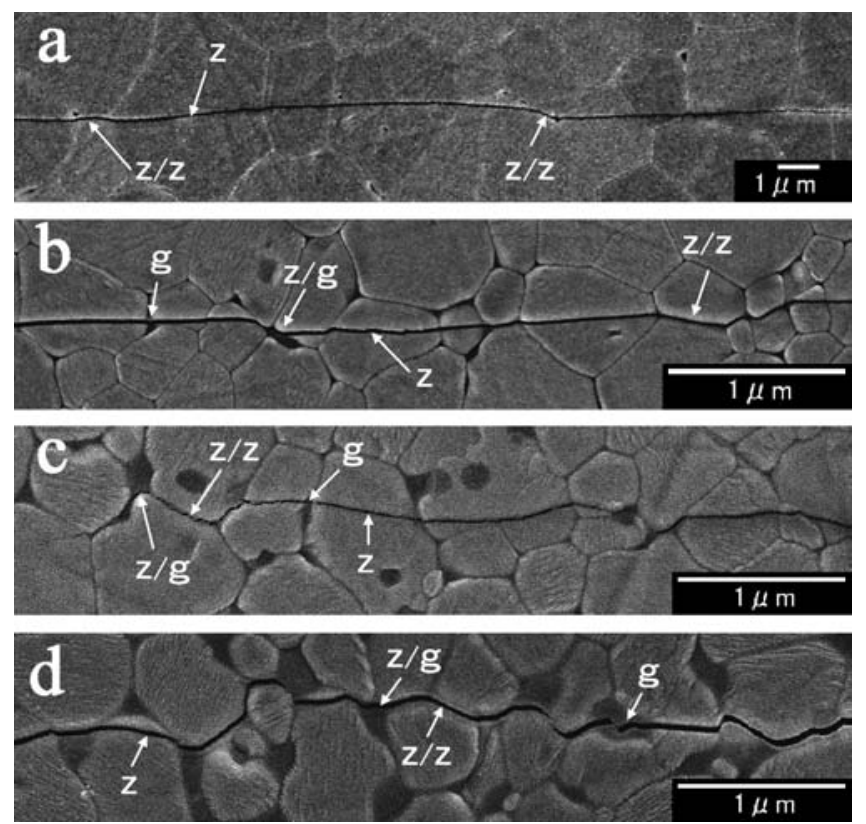

Fig. 5 SEM observation of crack paths in materials doped with (a) 0.15 , (b) 0.7 , (c) 2.0 and (d) 5.0 mass $\% \mathrm{SiO}_{2}$ for $d=$ $2.4 \mu \mathrm{m}((\mathrm{a}))$ and $d=0.75 \mu \mathrm{m}((\mathrm{b})-(\mathrm{d}))$. In (a), the crack passes through the matrix grains except for two short grainboundary segments $(z / z)$.

ぞ 1.0 よりも大きな值をとる. それぞれの $\mathrm{SiO}_{2}$ 添加量に対 して，10 個以上の圧痕を対象に亀裂の先端領域を計測して Fig. 6 の結果を得た。これより $\mathrm{SiO}_{2}$ 添加 $8 \mathrm{Y}-\mathrm{CSZ}$ における 亀裂伝播挙動について下記の知見が得られる.

第一に, ガラス相を貫く亀裂のセグメントの割合 $F_{\mathrm{g}}$ はガ ラス相の量にほぼ比例して増加する。しかし $F_{\mathrm{g}}$ の值自体は $V_{\mathrm{g}}$ の值よりも小さい (Fig. 6(b)). すなわち, 亀裂のガラス 相への進入は, ガラス分散組織のランダム切断から予期され るよりも小さな割合で生じている。したがって，少なくとも 本研究のように母相の結晶粒よりも小さな寸法で分散するガ ラス相 (Fig. 1)は, 亀裂伝播の優先経路とはならないと結論 できる.

第二に, $V_{\mathrm{g}}$ の増加は亀裂の粒内進入の割合 $F_{z}$ を減少させ (Fig. 6(a)), $\mathrm{ZrO}_{2}$ 粒界ないし $\mathrm{ZrO}_{2} /$ ガラス相界面への進入 割合 $F_{z / z}+F_{z / \mathrm{g}}$ を増加させている(Fig. 6(b))． $V_{\mathrm{g}} \sim 5 \mathrm{vol} \%$ で現れる $F_{z / z}$ の飽和は単位体積当たりの $\mathrm{ZrO}_{2}$ 粒界の数が減 少することと関連付けられる. 以上のデータは, 少なくとも ある部分の粒界や $\mathrm{ZrO}_{2}$ /ガラス相界面では, 亀裂伝播に対す る抵抗力が粒内よりも弱いことを示している．この点につい ては詳細な検討が今後必要であるが，粒界における抵抗力の 低下は Si の粒界偏析と関連することが示唆される．また， $\mathrm{ZrO}_{2} /$ ガラス相界面に打ける抵抗力の減少については, 両相 間での弾性率や熱膨張のミスマッチに起因した残留応力に関 係するものと考えられる.

最後に, 伝播経路の変遷と微視的な亀裂形状の変化とは同 時に生じている. Fig. 6(c)に示すように，ジグザグの程度 は $V_{\mathrm{g}}$, すなわち $F_{z / \mathrm{z}}+F_{z / \mathrm{g}}$ の増加とともに増している. Fig. 5 に見られるようなジグザグは, 亀裂の伝播する $\mathrm{ZrO}_{2}$ 粒界 および $\mathrm{ZrO}_{2} /$ ガラス相界面が巨視的な亀裂の進展方向に対し て傾斜あるいは捻れているために生じる。したがって, $F_{z / z}$ 


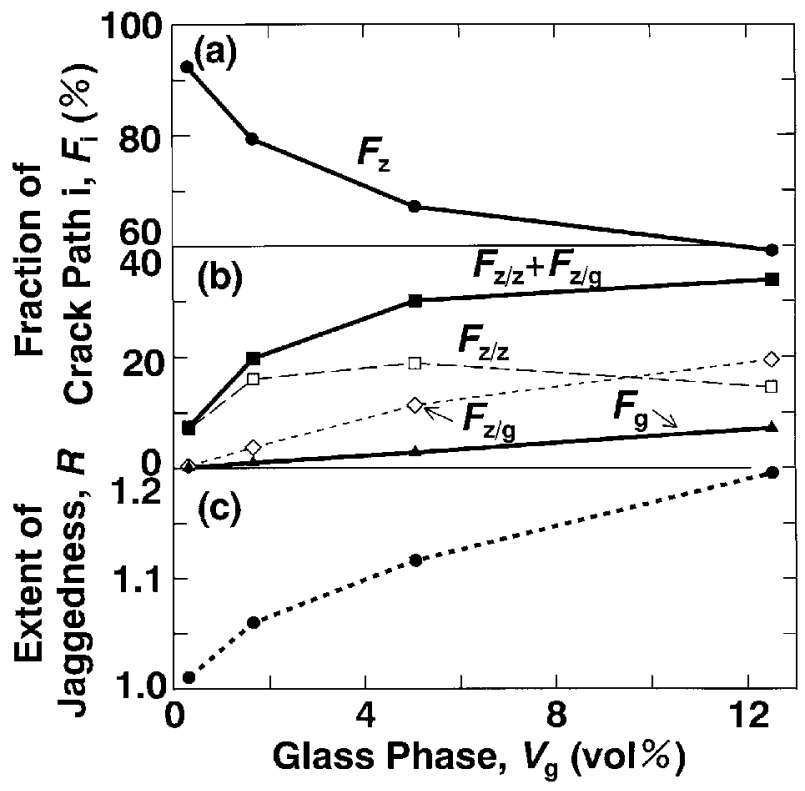

Fig. 6 Evolution in the crack paths ( (a) and (b)) and the extent of crack-jaggedness ((c)) as a function of the amount of the glass phase. The specimens examined are the same as those shown in Fig. 5.

$+F_{z / \mathrm{g}}$ とともにジグザグの程度が増すことは必然の傾向であ る.

上記の第二および最後のポイントは, $\mathrm{ZrO}_{2}$ 粒界および $\mathrm{ZrO}_{2} /$ ガラス相界面が亀裂偏向機構の場として働くことを指 し示している. 一般に, 亀裂偏向は強化相の分散による破壊 靱性の向上効果 ${ }^{28)}$ と関連付けて論じられる.しかしこの機 構は，何らかの組織的因子が亀裂の前縁を傾斜あるいは捻れ させ，これによって亀裂進展方向に対して垂直な方向に凹凸 成分を持った亀裂34-36) が生じれば働く。このような平坦で ない亀裂を生じさせる因子として，弱い粒界 ${ }^{36)}$ や界面 $\left.28,34,35\right)$ の存在ならびに母相と分散相の弾性率や熱膨張率の差に起因 する残留応力 ${ }^{34,35)}$ の存在が挙げられる. 亀裂伝播抵抗の低い 粒界や界面の生成は $\mathrm{SiO}_{2}$ を添加した $8 \mathrm{Y}-\mathrm{CSZ}$ にも該当す る. 先述のように, $\mathrm{ZrO}_{2}$ とガラス相の間の弾性率や熱膨張 のミスマッチも亀裂伝播に対する粒界や界面の抵抗力を減少 させることに寄与すると考えられる. 本研究の結果は, この ような亀裂偏向の効果が, 破壊靶性值を増大させるほどには 強くないが，ガラス相の破壊靱性值が低いことによるマイナ ス効果 (Fig. 3(b)の破線)を相殺するには十分な程度である ことを示している.

\section{4. 結 論}

(1) 正方晶ジルコニア $(8 \mathrm{Y}-\mathrm{CSZ})$ に純 $\mathrm{SiO}_{2}$ を添加する と, 粒界ファセットや多重点に均一に分散したガラス相のポ ケットが形成される. その量は 0.15-5.0 mass\%の $\mathrm{SiO}_{2}$ 添加 に対して 0.3-12.5 vol\%であり，Si の粒内固溶が無視できる 程度でかつ偏析量に飽和值があるとして説明できる.

（2）ガラス相の分散量の増加は弾性率，ビッカース硬さお よびヤング率と硬さの比を減少させる一方，インデンテーシ ヨン法で計測した破壊䩲性值にほとんど影響を与えない。後
者は，ガラス相の増加とともに一定荷重に対する亀裂長さが 減少し, 弾性率と硬さの比の減少が相殺されるためである.

（3）母相の粒径よりも小さなガラスポケットは亀裂の容易 伝播経路とはならなず, $\mathrm{SiO}_{2}$ 添加材の粒界と $\mathrm{ZrO}_{2}$ /ガラス 相界面は亀裂偏向機構の場として働く. その効果は破壊靱性 值の増大をもたらすほどには強くないが，ガラス相の破壊鞁 性值が低いことによるマイナス効果を相殺するには十分な程 度である。

\section{文献}

1) B. C. H. Steele: J. Mater. Sci. 36(2001) 1053-1068.

2) N. Q. Minh: J. Am. Ceram. Soc. 76(1993) 563-588.

3) M. C. Martin and M. L. Mecartney: Solid State Ionics 161 (2003) 67-69.

4) A. A. Sharif, P. H. Imamura, T. E. Mitchell and M. L. Mecartney: Acta mater. 46(1998) 3863-3872.

5) A. A. Sharif and M. L. Mecartney: Acta mater. 51(2003) 16331639.

6) P. M. Kelly and L. R. Francis Rose: Progress in Mater. Sci. 47(2002) 463-557.

7) O. Vasylkiv, Y. Sakka and V. V. Skorokhod: Mater. Trans. 44(2003) 2235-2238.

8) N.-H. Kwon, C.-H. Kim, H. S. Song and H.-L. Lee: Mater. Sci. Eng. A299 (2001) 184-194.

9) M. Nabbaro, P. Recio, J. R. Jurado and P. Duran: J. Mater. Sci. 30(1995) 1949-1960.

10) L. Donzel and S. G. Roberts: J. Euro. Ceram. 20(2000) 25472462.

11) R. A. Cutler, J. R. Reynolds and A. Jones: J. Am. Ceram. Soc. 75(1992) 2173-2183.

12) M. Gust, G. Goo, J. Wolfenstine and M. L. Mecartney: J. Am. Ceram. Soc. 76(1993) 1681-1690.

13) Kajihara, Y. Yoshizawa and T. Sakuma: Acta metall. mater. 43(1995) 1235-1242.

14) Y. Ikuhara, P. Thavorniti and T. Sakuma: Acta mater. 45 (1997) $5275-5284$

15) K. Hiraga, H. Y. Yasuda and Y. Sakka: Mater. Sci. Eng. A234236 (1997) 1026-1029.

16) K. Morita, K. Hiraga and B.-N. Kim: Acta mater. 52(2004) $3355-3364$.

17) M. L. Mecartney: J. Am. Ceram. Soc. 70(1987) 54-58.

18) L. Gremillard, T. Epicier, J. Chevalier and G. Fantozzi: Acta mater. 48(2000) 4647-4652.

19) L. Gremillard, J. Chevalier, T. Epicier and G. Fantozzi: J. Am. Ceram. Soc. 85 (2002) 401-407.

20) F. F. Lange, H. Shubert, N. Claussen and M. Rühle: J. Mater. Sci. 21(1986) 768-774.

21) I.-W. Chen and X.-H. Wang: Nature 404(2000) 168-171.

22) M. I. Mendelson: J. Am. Ceram. Soc. 52 (1969) 443-446.

23) K. Hiraga, K. Nakano, T. S. Suzuki and Y. Sakka: J. Am. Ceram Soc. 85 (2002) 2763-2770.

24) G. R. Antis, P. Chanticul, B. R. Lawn and D. B. Marshall: J. Am. Ceram. Soc. 64(1981) 533-538.

25) D. B. Marshall, T. Noma and A. G. Evans: J. Am. Ceram. Soc. 65(1982) C-175-C-176.

26) R. Raj: J. Am. Ceram. Soc. 64(1981) 245-248.

27) W. C. Butterman and W. R. Foster: Phase Diagrams for Zirconium and Zirconia Systems, Ed. by H. M. Ondik and H. F. McMurdie, (The American Ceramic Society, Westerville, OH, 1998) pp. 134.

28) K. K. Chawla: Composite Materials, (Springer-New-York, NY, 1998) pp. 235-344.

29) M. Hukuhara and A. Sanpei: Jpn. J. Appl. Phys. 33(1994) 2890-2893.

30) E. L. Bourhis and D. Metayer: J. Non-Cryst. Solids 272(2000) 34-38.

31) J. P. Lucas: Scripta Metall. Mater. 32 (1995) 743-748.

32) M. F. Ashby: Acta metall mater. 41 (1993) 1313-1335.

33) Bhargava and B. R. Patterson: J. Am. Ceram. Soc. 80 (1997) 1863-1867.

34) K. T. Faber and A. G. Evans: Acta metall. 31(1983) 565-576.

35) K. T. Faber and A. G. Evans: Acta metall. 31(1983) 577-584.

36) B.-N. Kim and T. Kishi: Mater. Sci. Eng. A176 (1994) 371-378. 